ADA 326925

\title{
Biodiversity Survey Guidelines With Emphasis on Threatened and Endangered Species
}

by

Clifford G. Rice
For Reference

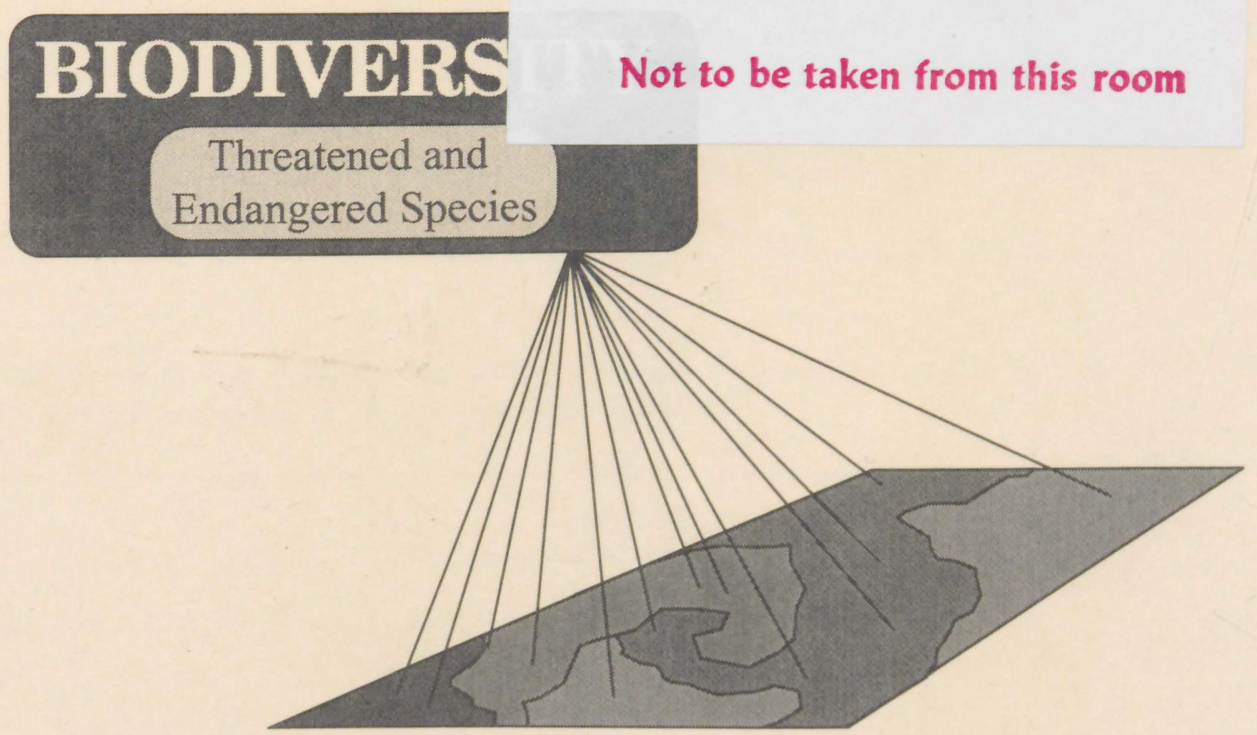

U.S. Army lands total nearly 12 million acres that must be managed in compliance with Federal and state environmental laws, including the Endangered Species Act. These legal requirements and stewardship objectives are the basis for the requirement that surveys of biodiversity and threatened and endangered species be conducted. These guidelines are intended to assist Army land managers in carrying out these surveys.
The guidelines are presented as an eight-step process as follows: (1) define objectives and scope, (2) gather background information on individual species, (3) gather background information on the survey area, (4) refine objective and scope, (5) prepare the survey plan, (6) obtain all permits and licenses (7) conduct the surveys, and (8) report the findings. Because these surveys often are completed under contract, sample items for developing scopes of work are included in an appendix. 
The contents of this report are not to be used for advertising, publication, or promotional purposes. Citation of trade names does not constitute an official endorsement or approval of the use of such commercial products. The findings of this report are not to be construed as an official Department of the Army position, unless so designated by other authorized documents. 


\section{USER EVALUATION OF REPORT}

REFERENCE: USACERL Technical Report 97/39, Biodiversity Survey Guidelines With Emphasis on Threatened and Endangered Species

Please take a few minutes to answer the questions below, tear out this sheet, and return it to USACERL. As user of this report, your customer comments will provide USACERL with information essential for improving future reports.

1. Does this report satisfy a need? (Comment on purpose, related project, or other area of interest for which report will be used.)

2. How, specifically, is the report being used? (Information source, design data or procedure, management procedure, source of ideas, etc.)

3. Has the information in this report led to any quantitative savings as far as manhours/contract dollars saved, operating costs avoided, efficiencies achieved, etc.? If so, please elaborate.

4. What is your evaluation of this report in the following areas?

a. Presentation:

b. Completeness:

c. Easy to Understand:

d. Easy to Implement:

e. Adequate Reference Material:

f. Relates to Area of Interest:

g. Did the report meet your expectations?

h. Does the report raise unanswered questions? 
i. General Comments. (Indicate what you think should be changed to make this report and future reports of this type more responsive to your needs, more usable, improve readability, etc.)

5. If you would like to be contacted by the personnel who prepared this report to raise specific questions or discuss the topic, please fill in the following information.

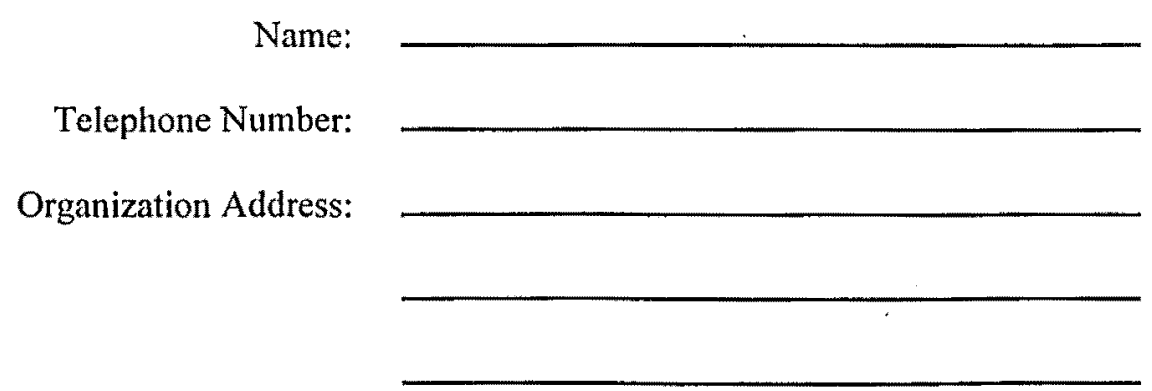

6. Please mail the completed form to:

Department of the Army

CONSTRUCTION ENGINEERING RESEARCH LABORATORIES

ATTN: CECER-TR-I

P.O. Box 9005

Champaign, IL 61826-9005 
Public reporting burden for this collection of information is estimated to average t hour per response, including the time for revieving instructions, searching existing data sources, gathering and maintaining the data needed, and completing and reviewing the collection of information. Send comments regarding this burden estimate or any other aspect of this collection of information, including stiggestions for teducing this burden, to Washington Headquarters Services, Directorate for information Operations and Repons, 1215 Jefferson Davis Highway, Suite 1204, Arlington, VA 22202-4302, and to the Office of Management and Budget, Paperwork Reduction Project (0704-0188), Washington, DC 20503.

\begin{tabular}{|l|l|l|}
\hline 1. AGENCY USE ONLY (Leave Blank) & $\begin{array}{c}\text { 2. REPORT DATE } \\
\text { January } 1997\end{array}$ & $\begin{array}{c}\text { 3. REPORT TYPE ANO DATES COVERED } \\
\text { Final }\end{array}$ \\
\hline
\end{tabular}

4. TITLE AND SUBTITLE

Biodiversity Survey Guidelines With Emphasis on Threatened and Endangered Species

6. AUTHOR(S)

Clifford G. Rice

7. PERFORMING ORGANIZATION NAME(S) AND ADDRESS(ES)

U.S. Army Construction Engineering Research Laboratories (USACERL)

P.O. Box 9005

Champaign, IL 61826-9005

9. SPONSORING / MONITORING AGENCY NAME(S) AND ADDRESSIES)

Assistant Chief of Staff for Installation Management

ATTN: DAIM-ED-R

600 Army Pentagon

Washington, DC 20310-0600

11. SUPPLEMENTARY NOTES

Copies are available from the National Technical Information Service, 5285 Port Royal Road, Springfield, VA 22161.

12a. DISTRIBUTION/AVAILABILITY STATEMENT

12b. OISTRIBUTION CODE

Approved for public release; distribution is unlimited.

13. ABSTRACT (Maximum 200 words)

U.S. Army lands total nearly 12 million acres that must be managed in compliance with Federal and statc environmental laws, including the Endangered Species Act. These legal requirements and stewardship objectives are the basis for the requirement that surveys of biodiversity and threatened and endangered species be conducted. These guidelines are intended to assist Army land managers in carrying out these surveys.

The guidelines are presented as an eight-step process as follows: (1) define objectives and scope, (2) gather background information on individual species, (3) gather background information on the survey area, (4) refine objective and scope, (5) prepare the survey plan, (6) obtain all permits and licenses (7) conduct the surveys, and (8) report the findings. Because these surveys often are completed under contract, sample items for developing scopes of work are included in an appendix.

\begin{tabular}{|c|c|c|c|}
\hline \multirow{2}{*}{$\begin{array}{l}\text { 14. SUBJECT TERMS } \\
\text { Biodiversity } \\
\text { Environmental compliance } \\
\text { Environmental management }\end{array}$} & \multirow{2}{*}{\multicolumn{2}{|c|}{ Endangered species }} & $\begin{array}{l}\text { 15. NUMBER OF PAGES } \\
36\end{array}$ \\
\hline & & & 16. PRICE CODE \\
\hline $\begin{array}{l}\text { 17. SECURITY CLASSIFICATION } \\
\text { OF REPORT } \\
\text { Unclassified }\end{array}$ & $\begin{array}{l}\text { 18. SECURITY CLASSIFICATION } \\
\text { OF THIS PAGE } \\
\text { Unclassified }\end{array}$ & $\begin{array}{l}\text { 19. SECURITY CLASSIFICATION } \\
\text { OFABSTRACT } \\
\text { Unclassified }\end{array}$ & $\begin{array}{l}\text { 20. LIMITATION OF } \\
\text { ABSTRACT } \\
\text { SAR }\end{array}$ \\
\hline
\end{tabular}




\section{Foreword}

This study was conducted for the Assistant Chief of Staff for Installation Management (ACS(IM)) under Project 4A162720A896, "Environmental Quality Technology"; Work Unit LN-TY5, "Inventory and Monitoring of Threatened and Endangered Species." The technical monitor was Phil Pierce, DAIM-ED-R.

The work was performed by the Natural Resource Assessment and Management Division (LL-N) of the Land Management Laboratory (LL), U.S. Army Construction Engineering Research Laboratories (USACERL). The USACERL principal investigator was Clifford G. Rice. Dr. David J. Tazik is Acting Chief, CECER-LL-N; and Dr. William D. Severinghaus is Operations Chief, CECER-LL. The USACERL technical editor was Gloria J. Wienke, Technical Resources.

COL James T. Scott is Commander and Dr. Michael J. O'Connor is Director of USACERL. 


\section{Contents}

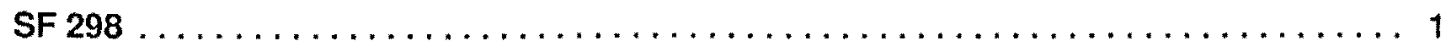

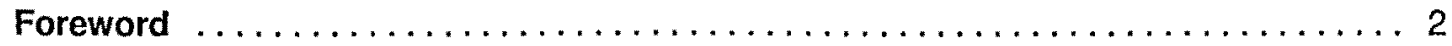

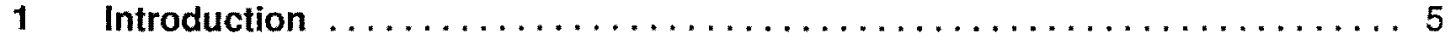

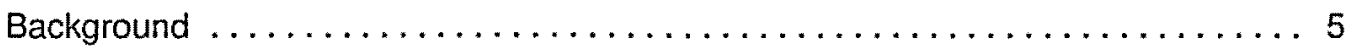

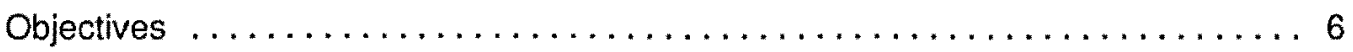

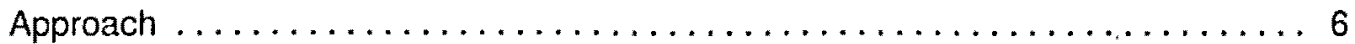

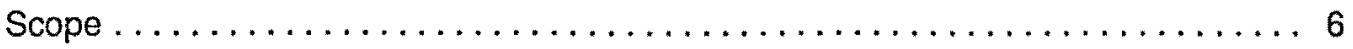

Mode of Technology Transfer $\ldots \ldots \ldots \ldots \ldots \ldots \ldots \ldots \ldots \ldots \ldots \ldots \ldots$

2 Process Overview $\ldots \ldots \ldots \ldots \ldots \ldots \ldots \ldots \ldots \ldots \ldots \ldots \ldots \ldots$

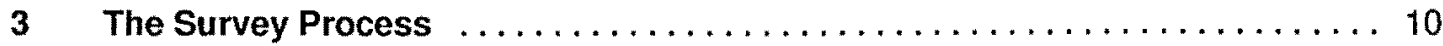

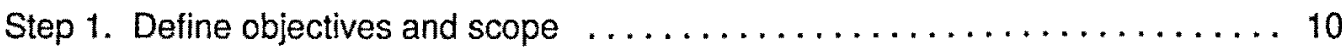

Step 2. Gather information about the identification, survey methodology, ecology, and status of species identified in Step $1 \ldots \ldots \ldots \ldots \ldots$

Step 3. Gather background information on the survey area $\ldots \ldots \ldots \ldots \ldots \ldots$

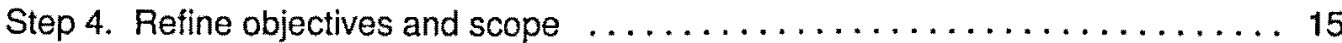

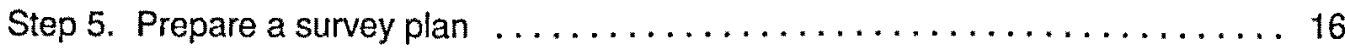

Step 6. Obtain all necessary licenses and permits $\ldots \ldots \ldots \ldots \ldots \ldots \ldots \ldots \ldots$

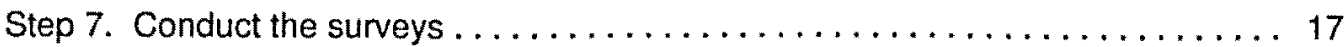

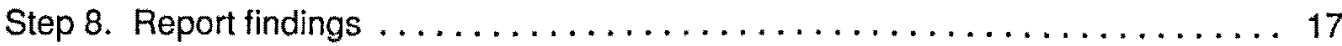

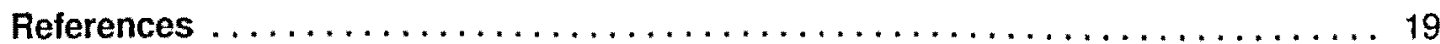

Appendix A:Work Elements for Scopes of Work for Performing Surveys $\ldots \ldots \ldots \ldots 21$

Appendix B:State Natural Heritage Program Offices $\ldots \ldots \ldots \ldots \ldots \ldots \ldots \ldots \ldots$

Appendix C:Selecting a Consultant $\ldots \ldots \ldots \ldots \ldots \ldots \ldots \ldots \ldots \ldots \ldots \ldots \ldots$

\section{Distribution}




\section{Introduction}

\section{Background}

Army installations are directed by Department of Army regulations (Army Regulation 200-3, Natural Resources - Land, Forest and Wildlife Management) and Federal law (such as the Endangered Species Act) to conserve endangered species and biodiversity." This is an important objective as Army lands total nearly 12 million acres, much of which remains in a natural or semi-natural state. Such areas contain extensive habitat for both endangered and other species of wildlife and plants. With the intensity of land use and consequent habitat modification increasing both on Army lands and elsewhere, the significance of the Army land in national biodiversity and endangered species conservation is steadily increasing. Accordingly, the Army has unequivocally stated its intention to be a national leader in natural resource stewardship, including the preservation and conservation of endangered species (U.S. Army 1992).

In addition to the broad policy directive to conserve biodiversity, the Endangered Species Act (Section 7) mandates far-reaching and specific procedures for ensuring that Federal agencies do not engage in activities that are likely to "jeopardize the continued existence" of an endangered species or destroy or adversely modify critical habitat. Specifically, the agency, in this case the Army, must consult with the U.S. Fish and Wildlife Service (USFWS) on any proposed activity (action) that the Army determines may affect a threatened or endangered species. If the USFWS concurs that the proposed activity "may affect" any threatened or endangered species, the Army should initiate formal consultation with the Service. Formal consultation concludes with the issuance of the Service's biological opinion, which determines whether the proposed action is likely to jeopardize the continued existence of a listed species or destroy or adversely modify any designated critical habitat. This process, known as Section 7 consultation, is described in detail in the Code of Federal Regulations, 50 CFR Part 402, and is summarized in Army Regulation (AR) 200-3, Chapter 11 .

\footnotetext{
Biodiversity has been defined as "...the variety of life and its processes, including the variety of living organisms, the genetic differences among them, and the communities and ecosystems in which they occur" (U.S. Department of Interior 1994). These guidelines focus on biodiversity at the species level.
} 
There is an obvious need for sound biological information for attaining policy objectives and meeting legislative obligations with regard to endangered species. One of the most basic and important types of information is the distribution and abundance of animal and plant species within an area of concern. The guidelines in this report have been developed to assist Army personnel in acquiring this essential information.

\section{Objectives}

The objectives of this report are to assist Army personnel in acquiring baseline information on biodiversity and endangered species in their area of jurisdiction and to provide a framework in which they can plan and carry out this task. The guidelines are intended as a source of advice on the subjects and issues that should be considered and addressed in completing biodiversity assessments. The surveys used to accomplish this should meet the approval of other government agencies. In addition, because most of the survey work is likely to be carried out under contract, these guidelines aim to assist Army personnel in developing accurate and meaningful scopes of work for those contracts.

\section{Approach}

The basic layout of these guidelines is a series of steps that should be taken by installation personnel wishing to complete a survey. By following the process described in each of these steps, it is anticipated that Army personnel will be able to obtain information needed for regulatory and legislative compliance and for making sound land management decisions. Probably, many of the steps described here will not be performed by Army personnel, but will be completed through contracted services.

\section{Scope}

Assessing the status of biodiversity and rare species on an installation can be viewed as having three sequential components: survey, inventory, and monitoring. These guidelines address the initial survey phase of these activities and are intended to give assistance in planning and conducting assessments of biodiversity, especially threatened and endangered species, on Army lands. 
In this context, inventory is a detailed and complete assessment of the status of the resource. These guidelines will help identify species or other elements for which an inventory is justified. Monitoring is the process by which changes in the resources are assessed, usually with reference to specific management goals and programs (as in adaptive management, [Holling 1978, Walters 1986]). The results from these surveys are considered crucial building blocks for the later efforts; guidance documents covering these subjects are under preparation. This report does not address biodiversity per se, specifically its definition (Keystone Center 1991) or measurement (Hawksworth 1995, Lovejoy 1995, May 1995, Noss 1990, O'Donnell, Goodfellow, and Hawksworth 1995, Whitworth and Hill 1997).

\section{Mode of Technology Transfer}

It is recommended that the process described in this report be used by the Army Environmental Center and Army personnel in planning, developing, and conducting or contracting biodiversity surveys. 


\section{Process Overview}

\section{Step 1. Define objectives and scope}

Initially, it is important to clearly define what the surveys are intended to encompass. This includes delineation of the geographic area of interest, an assessment of what information is needed and how it should be reported, a review of particular species that may be present, consultation with regulatory personnel and local experts, and an assessment of the expertise that will be needed to complete the survey.

Step 2. Gather information about the identification, survey methodology, ecology, and status of species identified in Step 1

This information will be needed for designing the surveys and interpreting their results.

\section{Step 3. Gather background information on the survey area}

Information on the plant communities and/or habitats present, land use, and the general physiography of the area will also be needed for designing the surveys.

\section{Step 4. Refine objectives and scope}

Steps 2 and 3 may bring to light information that calls for modification of the scope identified in Step 1.

\section{Step 5. Prepare a survey plan}

This written plan presents the findings made during Steps 1 through 4 . It should also detail specific survey methods for each taxonomic group to be surveyed and the sampling design. 


\section{Step 6. Obtain all necessary licenses and permits}

State and Federal permits will be needed if surveys involve collecting plant or animal specimens, capturing animals, or disturbance of threatened or endangered species.

\section{Step 7. Conduct the surveys}

\section{Step 8. Report findings}

In addition to the results of the surveys, this report should make an assessment of the adequacy of the survey effort and make an evaluation of the potential implications of the findings for biodiversity conservation and base operations. 


\section{The Survey Process}

Work elements relevant to each of the steps are given in Appendix A.

\section{Step 1. Define objectives and scope}

Ideally, a biodiversity assessment would assess the status of every species in all parts of a given installation. However, funds are limited and there may be time constraints for particular objectives such as endangered species surveys.

A basic consideration that needs to be addressed at the beginning of this step is whether one intends to do a biodiversity overview, a complete species inventory, or an assessment of the status of a particular endangered species (Table 1). For a biodiversity overview, the objective is to assess the general biodiversity present in the area by sampling a number of sites. The Army's Land Condition Trend Analysis (LCTA) program (Tazik, et al. 1992) can provide this sort of overview, but "additional data sources should be utilized to address known deficiencies and gaps in coverage" (Whitworth and Hill 1997). For a species inventory, essentially all areas would need to be intensively searched and surveyed in an attempt to document every species present. For endangered species surveys, particular habitats might be intensively surveyed with methods tailored to the target species. All three of these types of surveys provide useful information and there would be considerable value in doing all three in the order listed. However, priorities and constraints vary and the installation may choose to focus on one of these. For instance, compliance with the Endangered Species Act requires the endangered species surveys be undertaken, but does not address the other two types of assessments. On the other

Table 2. Types of biodiversity assessments, their benefits, and approaches

\begin{tabular}{|l|l|l|}
\hline $\begin{array}{l}\text { Type of } \\
\text { Assessment }\end{array}$ & Benefit & Approach \\
\hline Biodiversity overview & $\begin{array}{l}\text { Identify areas/communities with high } \\
\text { biodiversity and some identification of } \\
\text { unique/rare species }\end{array}$ & $\begin{array}{l}\text { Establish sampling areas } \\
\text { throughout installation }\end{array}$ \\
\hline $\begin{array}{l}\text { Complete species } \\
\text { inventory }\end{array}$ & $\begin{array}{l}\text { List of all species present, not just } \\
\text { relatively common or expected species }\end{array}$ & $\begin{array}{l}\text { Requires extensive } \\
\text { sampling and searching }\end{array}$ \\
\hline $\begin{array}{l}\text { Endangered species } \\
\text { status }\end{array}$ & $\begin{array}{l}\text { Information focused on particular species } \\
\text { with specific information need }\end{array}$ & $\begin{array}{l}\text { Customized in extent } \\
\text { and methods }\end{array}$ \\
\hline
\end{tabular}


hand, compliance with Army policy and regulations with regard to biodiversity conservation and ecosystem management would require all three (AR 200-3). Each installation must assess the survey requirements for the areas under their jurisdiction.

It may be desirable to prioritize surveys for particular species or groups of species. The official list of threatened, endangered, and candidate species can be obtained from the USFWS. Completing surveys for candidate species is advisable in that documenting their occurrence may enable conservation prior to listing, thus avoiding the need for listing. Even in more comprehensive assessment efforts, it may be necessary to partition this major effort into several areas of focus as the context and design may vary dramatically from one area to the next, necessitating essentially separate planning and field operations. For instance, surveys for aquatic or cavedwelling organisms require fundamentally different approaches and might be best handled separately. On the other hand, opportunities for parallel, complimentary, and integrated planning and sampling should be used. Small installations may be able to combine all these considerations in a single survey effort.

It may also be desirable to set priorities for assessment efforts based on a geography. Some parts of an installation may be considered more or less important for survey efforts. For instance, areas that are perceived to be biologically rich might be considered for more intensive sampling than allocated to biologically impoverished areas. It may also be desirable to give greater emphasis to areas with perceived biodiversity impacts (training areas) or to those with impacts anticipated in the future. Table 2 presents some factors that might be considered in sampling allocation decisions. Each state Natural Heritage Program has a listing of rare plant communities; that list should be consulted. In some cases, the geographic area of

Table 2. Some factors influencing survey intensity and priority (modified from Nelson 1985)

\begin{tabular}{|l|l|l|}
\hline Factor & More intensive survey & Less intensive survey \\
\hline Impacts & $\begin{array}{l}\text { Areas that will be disturbed } \\
\text { in the future }\end{array}$ & Areas not to be disturbed \\
\hline Plant community & $\begin{array}{l}\text { Communities known to support } \\
\text { rare species or high diversity }\end{array}$ & $\begin{array}{l}\text { Community types known not to } \\
\text { support rare species or high diversity }\end{array}$ \\
\hline Plant community & Locally rare community & Widespread community type \\
\hline $\begin{array}{l}\text { Vegetation } \\
\text { density }\end{array}$ & $\begin{array}{l}\text { Dense vegetation, tall canopies, } \\
\text { thick understory }\end{array}$ & Open vegetation with good visibility \\
\hline Naturalness & Less disturbed and degraded & More disturbed and degraded \\
\hline Species visibility & Cryptic or small species & Species that are easily noticed \\
\hline Soil & Uncommon/unusual soil type & Common soil type \\
\hline Fragmentation & $\begin{array}{l}\text { Highly heterogeneous or } \\
\text { isolated areas }\end{array}$ & Uniform areas \\
\hline Mission change & Change is highly probable & Static mission \\
\hline
\end{tabular}


interest may extend beyond installation boundaries. This would be appropriate if cooperative management with neighboring land managers is anticipated.

The detail of the information required is an important matter for consideration at this stage. For instance, is simple presence and absence information for a given species sufficient, or is some measure of population status or density needed? Might it be valuable to include some information relating to population parameters such as reproduction or population age structure?

For the species of interest, it should be determined which are likely to be present based on their geographic distribution. The local USFWS Field Office (for terrestrial and freshwater species), the National Marine Fisheries Service (NMFS; for marine and anadromous species) and the state Natural Heritage Program (Appendix B) can provide information on probable occurrences for a particular area. If it has not already been incorporated into these data sources, additional distributional information can be obtained from historic records, biological collections (e.g., museums), local experts, published materials, and communications with other government agencies.

Contact with concerned government agencies should also be established at this point to provide input on defining the scope and objectives for the assessment. If the survey is for the purpose of ending non-compliance or avoiding non-compliance with a government regulation, or if it is a mitigative activity spawned from some other process, it is imperative that frequent, if not constant, communication occur between the installation and the regulatory agency concerning the development, execution, and reporting of the survey. Of primary importance in this interaction are the USFWS and the state wildlife agency. Other agencies that may provide valuable input are the Biological Resources Division of the U.S. Geological Survey (formerly the National Biological Survey), National Park Service, U.S. Forest Service, the U.S. Department of Agriculture Natural Resources Conservation Service (NRCS), the Bureau of Land Management, the Bureau of Reclamation, the state Natural Heritage Program, and local societies or chapters of societies such as rare plant societies, the Audubon Society, the Sierra Club, and Defenders of Wildlife.

It is also necessary to identify the types of expertise that will be needed to carry out Steps 2 through 8 given the scope and objectives identified above. Such an assessment would include a consideration of the ability to classify/identify species involved, knowledge of specialized survey techniques, the ability to analyze data collected, and ability to present the survey findings in an organized, comprehensive, and meaningful way. Installation personnel need to assess the capabilities of their staff with regard to these requirements and determine which of the steps outlined 
here will be accomplished by Army personnel and which will be contracted. Choosing the right consultant can be crucial in determining the success of the survey effort. Some considerations in selecting a consultant are outlined in Appendix C.

All of these considerations bear on the determination of the form and mediums required for delivery and storage of the information. Step 1 should include the requirement for a report of the findings; it should also specify which of the following may be required: raw data; database of surveys performed (place, time, extent); Global Positioning System (GPS) use and standards; or Geographical Information System (GIS) formatted output.

\section{Step 2. Gather information about the identification, survey methodology, ecology, and status of species identified in Step 1}

Depending on the scope that was defined in Step 1, much of this information gathering will be done for groups of species such as all birds, or all herpetofauna. On the other hand, for very focused surveys for particular species, a more narrowly directed effort will be appropriate.

Obviously, to carry out surveys, the species involved must be identified correctly. For some species, such as birds, accurate and comprehensive field guides are available. For most other taxonomic groups, more technical treatments will need to be located. For instance, popular mammal field guides are fine for large, conspicuous species, but sometimes they don't contain sufficient information to accurately identify small mammals. Likewise, popular plant guides usually cover only the most common and conspicuous species. Comprehensive floral descriptions will be needed for floristic surveys. Those involved with the field surveys need to be experienced in making species identifications, not merely familiar with the general concepts. If this expertise is not available at the onset, adequate time for familiarization and practice must be included in the survey plan.

For many species, it may be necessary to collect specimens for correct identification. Information on collecting procedures and the labeling, preservation, and eventual disposition of these specimens should also be assembled.

Collecting, trapping, and other types of survey activities will require permits. If the survey plan calls for collecting voucher specimens of animals or trapping, a state wildlife collecting permit will probably be required. Local offices of state and Federal agencies should be contacted to determine permit requirements for the anticipated surveys. If university personnel are involved in capturing or handling 
of wildlife, the approval of the university's humane use committee may be necessary. If the survey protocol involves any of the definitions of "taking" identified in the Endangered Species Act (e.g., harass, harm, pursue, hunt, shoot, wound, kill, trap, capture, collect, or attempt to do any of these), a permit must be obtained from the USFWS (per Section 10 of the Endangered Species Act). Such activities with regard to state listed species may also incur additional state permitting requirements. In some cases, obtaining permits may take a year.

Survey methods vary widely both within and between taxonomic groups. In many cases, several survey methods have been developed for a given taxonomic group. It will be necessary to evaluate existing methods to determine the most appropriate method for the anticipated survey. If existing methods are, for some reason, not appropriate, customized methods may need to be developed. Careful consideration should also be given to methods used elsewhere in the region and historically so that the resulting information can be readily compared with that from other efforts.

The time(s) of year for conducting survey work also needs to be considered. Local or long-distance migrations may profoundly affect the occurrence of some species. Plant phenology is another significant factor that must be taken into account and an inventory of all plant species may necessitate surveys at several different times of the year. Some methods, such as call counts for birds and amphibians, are highly influenced by seasonal changes and are best conducted during the breeding season.

A knowledge of the ecology of the species to be surveyed is essential for assessing the most appropriate survey methods and in interpreting the results. Such factors include reproductive cycle or phenology, migration, home range and movements, habitat preferences, and social structure. For many species, such detailed information will not be available, but when it is available, it should be considered in survey design. For surveys that focus on a particular species, detailed information on ecology will help focus the effort in appropriate areas. For instance, a species may have quite particular habitat requirements or seasonal movement patterns. An understanding of those factors is essential for designing survey protocols.

For efforts focused on one or a few species, this information gathering should include an account of the status of the species in national, regional, local, and historic contexts. Specifically, populations (or individuals) previously recorded in the survey area should be identified.

Apart from reviewing published reference material to gather this background information, local experts and agency personnel mentioned in Step 1 should also be queried; these people may have considerable knowledge that has not been published. 
If the USFWS has prepared a recovery plan for any of the species of interest, this should be a valuable source of information.

\section{Step 3. Gather background information on the survey area}

For survey planning and reporting the results, it is necessary to have a sound understanding of the nature of the area being assessed. Such information should include topographic maps, aerial photographs, soil surveys, planning documents (e.g., environmental impact assessments), natural resource inventories, and hydrology and land use patterns. Ideally, one should obtain or develop a map of vegetation communities on all parts of the survey area. The map should use a recognized regional standard community classification system (such as used by the state Natural Heritage Program, the National Park Service, or the Biological Resources Division of the U.S. Geological Survey ${ }^{*}$ ). Minimally, one should have a list of community types present in the area or region and an idea of which types are considered rare. In addition, special habitat features identified for particular species of interest in Step 2 should be identified and mapped, if feasible.

Detailed vegetation mapping is a time-consuming and expensive process, but should meet basic Federal and Army standards. ${ }^{* *}$ Therefore, the degree of detail and refinement in the vegetation classification should be carefully considered. This will depend on the objectives of the assessment, but would likely focus on the alliance or community type level of classification. If the primary concern is with ecosystem, community, or general biodiversity assessment, the mapping should be as detailed in its classification scheme as possible. On the other hand, if the effort is directed primarily at achieving compliance for endangered species surveys, a focus on certain specific characteristics may be sufficient to identify important habitat features and will be more cost-effective (at least in the short term).

\section{Step 4. Refine objectives and scope}

Information collected in Steps 2 and 3 may call for modifications to the scope identified in Step 1. For instance, if the installation is within the geographic range of a particular endangered species, it may have been identified for survey in Step 1.

\footnotetext{
This vegetation classification and mapping system is currently under development. Further details are available from: http://www.nbs.gov/npsveg and ftp://ftp.ttc.nbs.gov/pub/vegmapping/classification.

** Both Federal and Army standards are currently under development under the Federal Geographic Data Committee (Federal Register Volume 59, pp. 17671-17674) and the project "Development and testing of Army standard protocols for vegetation mapping" (P. Dubois, Ecologist, Army Environmental Center, 12 April 1996, pers. comm.).
} 
However, if the species has narrow and specialized habitat requirements (identified in Step 2) and this habitat is not present on the installation (Step 3), surveys for this species may not be necessary. Likewise, Step 3 may identify habitats that were not known to be present and may deserve special attention because they are unique or rare, or are thought to have a high level of biological diversity.

It will also be necessary to select the specific methods to be used in the survey. Those selected should be judged by the following criteria:

1. Represent recognized standard methods

2. Acceptable to the scientific community and regulatory agencies (USFWS)

3. Identical or comparable to methods used historically or regionally

4. Cost-effective

5. Provide information on population processes as well as population status

6. Accurate, precise, and robust to observer variability

7. Unambiguously defined

8. Repeatable.

\section{Step 5. Prepare a survey plan}

The survey plan is a detailed written plan that presents the findings made during Steps 1 through 4. It should, therefore, contain sections on the objectives and scope of the survey effort, a description of the site and its vegetation communities, details of sampling methodology for each species or group of species, and details of the sampling strategy and sampling allocation. For many species, standard protocols for performing surveys can be obtained from USFWS Field Offices. The sampling methodology and allocation should be unambiguously defined so that, should the surveys be repeated in the future, this plan will be sufficient to guide that effort. In addition, the rationale used in selecting methods and determining sampling procedures should be described. For instance, include the characteristics of the field methods considered important in making the selection. State whether the samples were randomly or subjectively distributed. List the criteria or system applied in determining sampling procedure and design (e.g., use of confidence intervals [Snedecor and Cochran 1972], statistical power [Cohen 1988], cluster sampling [Thompson 1992], species area relationships [Mueller-Dombois and Ellenberg 1974], or the relevè method [Barbour, et al. 1980, Mueller-Dombois and Ellenberg 1974], to name a few possibilities). Procedures for site documentation such as marking permanent plots (e.g., GPS) or making photographic records should also be specified. 
For many taxonomic groups, voucher specimens should be collected. The survey plan should provide details on protocols to be used for collection, labeling, preservation, and disposition of all specimens collected. These protocols should be consistent with those of the institution that will eventually house the specimens.

At this stage it is advisable to obtain a review of the survey plan from organizations that are likely to review and assess the results. This would include the USFWS, state agencies, and any interested non-governmental organizations.

The survey plan should also include a methodology for coordinating all survey activities with appropriate installation personnel.

\section{Step 6. Obtain all necessary licenses and permits}

Proceed with the requirements identified in Step 2.

\section{Step 7. Conduct the surveys}

The surveys should be carried out according to the plan described in Step 5 and any departures from that plan should be documented.

\section{Step 8. Report findings}

As the one document that contains all the relevant information from the survey effort, the survey report should include a comprehensive review of the development, planning, and outcome of the survey effort. The report should state explicitly what the background, goals, and objectives of the survey were, and should contain a detailed description of the methods and sampling procedures used. Complete records of the location and status of rare, sensitive, threatened, or endangered species should be sent to the state Natural Heritage Program for inclusion in their database. Because the exact location and extent of specific populations of rare species is of major importance, the results of the survey(s) should be reported in considerable detail, but these details should be reviewed and summarized in the context of the management area to which they are relevant. Information on historic records of species should also be included. Any particular ecological features or elements (e.g., wetland or a geological feature) that are important in sustaining biodiversity should be identified and the role of these features described. The implications of the findings for the conservation of biodiversity and land use and land 
management activities should also be discussed. Finally, priorities for future activities should be discussed with respect to three areas: protection, management and land use, and further information gathering. 


\section{References}

Army Regulation (AR) 200-3, Natural Resources - Land, Forest and Wildlife Management (Headquarters, Department of the Army [HQDA] 28 February 1995.

Barbour, M.G., J.H. Burk and W.D. Pitts, Terrestrial Plant Ecology (The Benjamin/Cummings Publishing Company, Inc., 1980).

Cohen, J., Statistical Power Analysis for the Behavioral Sciences, 2nd ed. (Lawrence Erlbaum Associates, 1988).

Hawksworth, D.L., ed., Biodiversity; Measurement and Estimation (Chapman \& Hall, 1995).

Holling, C.S., Adaptive Environmental Assessment and Management (International Ins., 1978).

Keystone Center, Final Consensus Report of the Keystone Policy Dialogue on Biological Diversity on Federal Lands (The Keystone Center, 1991).

Lovejoy, T.E., "The Quantification of Biodiversity: An Esoteric Quest of a Vital Component of Sustainable Development," in D.L. Hawksworth, ed., Biodiversity; Measurement and Estimation (Chapman \& Hall, London, 1995), pp 81-87.

May, R.M., "Conceptual Aspects of the Quantification of the Extent of Biological Diversity," in D.L. Hawksworth, ed., Biodiversity; Measurement and Estimation (Chapman \& Hall, London, 1995), pp 13-20.

Mueller-Dombois, D. and H. Ellenberg, Aims and Methods of Vegetation Ecology (J. Wiley \& Sons, 1974).

Nelson, J.R., "Rare Plant Surveys: Techniques for Impact Assessment," Natural Areas Journal, vol 5 no. 3 (1985), pp 18-30.

Noss, R.F., "Indicators for Monitoring Biodiversity: A Hierarchical Approach," Conservation Biology, vol 4 no. 4 (1990), pp 355-364.

O'Donnell, A.G., M. Goodfellow, and D.L. Hawksworth, "Theoretical and Practical Aspects of the Quantification of Biodiversity Among Microorganisms," in D.L. Hawksworth, ed., Biodiversity; Measurement and Estimation (Chapman \& Hall, London, 1995), pp 65-73.

Snedecor, G.W. and W.G. Cochran, Statistical Methods, 6th ed. (Iowa State University Press, 1972). 
Tazik, D.J., S.D. Warren, V.E. Diersing, R.B. Shaw, R.J. Brozka, C.F. Bagley, and W.R. Whitworth, U.S. Army Land Condition-Trend Analysis (LCTA) Plot Inventory Field Methods, Technical Report N-92/03/ADA 247931 (U.S. Army Construction Engineering Research Laboratories [USACERL], February 1992).

Thompson, S., Sampling (John Wiley \& Sons, Ine., 1992).

U.S. Army, U.S. Army Environmental Strategy Into the 21st Century (Army Environmental Policy Institute, 1992).

U.S. Department of Interior (USDI), Ecosystem Approach to Wildlife Conservation (March 1994).

Walters, C., Adaptive Management of Renewable Resources (MacMillan Publishing Company, 1986).

Whitworth, W.R. and A. Hill, Applicability of Land Condition Trend Analysis Data for Biological Diversity Assessment in the Southeastern United States, USACERL Technical Report 97/67 (USACERL, April 1997). 


\section{Appendix A: Work Elements for Scopes of Work for Performing Surveys}

The following work elements may be assembled into groups to define the tasks in a Scope of Work for a contract. The level of detail required may vary considerably. For instance, detailed information on every species would not be desirable for a general biodiversity survey, or a thorough taxonomic review may not be necessary for well-known vertebrates, whereas it might be considered essential for plants or invertebrates.

\section{Step 1. Define objectives and scope}

Out of necessity, most of the scoping described in Step 1 will have to be done by installation personnel because much of this has to do with setting priorities.

\section{Step 2. Gather information about the identification, survey methodology, ecology, and status of species identified in Step 1}

1. Determine the classification and nomenclature of the taxon, including the following information:

A. Scientific name.

i. Bi - or trinomial with author(s) and full bibliographic citation(s).

ii. Type specimen.

B. Synonyms with full bibliographic citations.

C. Common names.

D. History of taxon.

E. Alternative systematic treatments of the taxon. Clarification of any taxonomic questions.

2. Determine the present legal or other formal status of the taxon.
A. International.
B. National.
C. State.

3. Provide the following descriptive information:
A. General non-technical description. 
B. Technical description.

C. Local field characters.

D. Original $35 \mathrm{~mm}$ color slides showing, as appropriate,

i. Adult and immature, juvenile, or larval stages, eggs, nests, or other taxon-specific features.

ii. Mature plant, flowers, fruits and vegetative structures.

E. Line drawing showing, as appropriate,

i. Adult and immature, juvenile, or larval stages, eggs, nests, or other taxon-specific features.

ii. Mature plant, flowers, fruits and vegetative structures.

4. Determine the geographical distribution of the taxon.

A. Prepare a range map depicting the distribution, by county, of the taxon. Symbolically represent the current status of each population (extant or extirpated).

B. Make a preliminary examination of the precise occurrences of the taxon by examination of museum or herbarium specimens, review of the literature, examination of Heritage Program data, discussions with knowledgeable amateur and professional biologists and any other available sources. Provide the following for each population:

i. State and county in which it occurs.

ii. Latitude and longitude.

iii. Population size (number of individuals) and area covered.

iv. Year of discovery.

v. Year of most recent observation or collection.

vi. Status according to the following categories:

(1) Extant populations.

(2) Extirpated populations, with reasons for loss.

(3) Historical populations with currently unknown status.

(4) Populations with ambiguous or incomplete locality information.

(5) Population reports believed to be erroneous, with explanation of why erroneous.

5. Make a preliminary characterization of the taxon's physical habitat and habitat requirements, including:

A. Description of its general environment and habitat, community associations.

B. Physical characteristics of its habitat such as climate (macro and micro), soils, physiographic province, physiographic and topographic relationships and taxon-environment interrelationships.

6. Review the ecology of the taxon, include:

A. Life history (as appropriate for the taxon).

i. Home range and movements. 
ii. Migration.

iii. Phenology.

iv. Mode of reproduction (as appropriate for the taxon).

(1) Nesting habits.

(2) Flowering, fruiting, and germination biology.

B. Interspecific interactions.

C. Demography.

i. Population sizes and densities.

ii. Reproductive rates.

iii. Mortality rates and causes.

D. Food Habits (as appropriate).

E. Special habitat characteristics.

F. Threats.

G. Management and research needs.

7. Review and compare methods for performing field surveys for the taxon, including:

A. Description of the methods.

B. Discussion of the advantages and disadvantages of each.

C. Recommendations on implementation of surveys for the taxon, including:

i. Selection of available methods or improvements or development of new methods.

ii. Temporal sampling considerations (seasonal, nocturnal, etc.).

D. Description of qualifications required for surveyors using this method.

E. Description of permits that will be required to execute such a survey, including:

i. Type of permit.

ii. Administering agency.

iii. Application procedure.

iv. Costs or fees.

\section{Step 3. Gather background information on the survey area}

1. Environmental characteristics.
A. Climate.
B. Topography.
C. Geology.
D. Hydrology.
E. Soils.

2. Major ecological community types present in the survey area. For each provide:

A. Name and formal classification system. 
B. Synonyms.

C. Rare species that occur in this community.

i. Plants.

ii. Animals.

iii. Other.

D. Characteristic species of the community.

E. Identifying characteristics of the community.

F. Location of examples of the community in the survey area.

G. Management guidelines for the community.

3. Status and losation of special habitat features for taxon of interest.

\section{Step 4. Refine objectives and scope}

It is anticipated that this reassessment of Step 1 will be done by installation personnel also, based on the findings presented in Steps 2 and 3.

\section{Step 5. Prepare a survey plan}

1. Essentially, all of the background work completed up to this stage should be incorporated into this plan. As such, it may be considered to have two functions:

A. A plan for the surveys to be conducted.

B. A draft of the sections of the final report that will deal with background information.

2. The plan should have the following parts:

A. Objectives and Scope. This presents the results of Step 4.

B. Description of Site. This presents the results of Step 3.

C. Review of Taxon. This presents the results of Step 2.1-2.6.

D. Variables to be recorded. This will differ substantially between taxonomic groups, but may include:

i. Biological characteristics of the taxon including:

(1) Vegetation physiognomy, community structure and regional vegetation type of locations surveyed.

(2) Species associated with significant elements, including other endangered, threatened, rare or special concern species.

(3) Dominance (cover or basal area) and frequency in each community type in which it occurs (for plants). 
ii. Population biology of the taxon including:

(1) Demography. Define age (size) classes and census methods used to determine area and number reported.

(a) Areas occupied by the populations (for localized taxons).

(b) Number and/or age or size classes of individuals in each population.

(c) Density of individuals in each population.

(d) Evidence of reproduction.

(e) Evidence of population trends (increasing, declining, etc.).

(f) Evidence of range expansion or compression.

(2) Phenology or life cycle information.

(3) Reproductive biology.

iii. Evidence of threats to survival such as:

(1) Present or threatened destruction, modification, or curtailment of habitat or range.

(2) Overuse for commercial, sporting, scientific, or educational purposes.

(3) Disease or predation.

(4) Inadequacy of existing regulatory mechanisms.

(5) Other natural or man-made factors.

E. Survey Method. Describe the survey method(s) recommended in Step 2.7. Include animal welfare considerations.

F. Sampling Design. On the basis of Step 4, using the method(s) recommended above, explicitly describe the distribution and intensity of sampling to be used with that method.

G. Specimen Protocol, including:

i. Guidelines explaining conditions and situations that will call for specimen collection.

ii. Description of preservation methods.

iii. Provisions for curation and disposition of the specimens.

H. Quality Assurance/Quality Control Plan.

i. Provisions for:

(1) Consistency.

(2) Accuracy.

(3) Error trapping.

(4) Data archiving.

(5) Documentation of survey execution. Maintain a database of field activities containing the following fields:
(a) Surveyor.
(b) Date.
(c) Name of area surveyed. 
(d) Taxon sought.

(e) GPS-referenced location of study plot and/or series of locations indicating search path.

(6) Suggested review process for the plan.

I. Proposed work schedule for completing the surveys including personnel breakdown.

J. Detailed description of provisions for coordinating field activities with other installation activities.

3. The plan should be written and organized in such a way that all or part of it can be used to develop the scope of work for execution of the surveys.

\section{Step 6. Obtain all necessary licenses and permits}

This must be done by the organization/persons who will carry out Step 7 .

\section{Step 7. Conduct the surveys}

Conduct the surveys according to the plan developed in Step 5.

\section{Step 8. Report findings}

The report of survey findings should cover the following topics:

1. Objectives and Scope. This section may be taken directly from the survey plan, but it should be written for a reader who may not have seen the plan.

2. Survey Area Description. Information in the survey plan should be sufficient for this section also.

3. Methods. Provide detailed description of the methods that were used including:
A. Type of survey (transects, point counts, trapping, search strategies)
B. Sampling procedures: the distribution of surveys in time in space.

4. Survey Results, specifically:
A. What was encountered.
B. How many, or how much was encountered.
C. Where the significant elements were encountered, and when.
D. Negative results: where were particular elements searched for and not encountered and, in particular, where were they expected, but not encountered.


5. Interpretation of Results.

A. Status: how do the results of the survey change our understanding of the status of the taxons of interest in local, regional, national, and international contexts.

B. Ecology: describe and summarize the findings of the survey in terms of the ecology of the species and/or communities of interest.

6. Management Implications:

A. How might these results affect base operations?

B. What additional information would be useful in pursuing biodiversity conservation objectives for the area?

C. What could or should be done to improve current conditions?

7. Prioritization of Biodiversity and Endangered Species Concerns.

A. Preservation.

B. Land use and management issues (other than preservation).

C. Further information needs.

8. Assessment of Adequacy.

A. Did the survey accomplish the objectives originally set out?

B. If not, what additional efforts would be appropriate? 


\section{Appendix B: State Natural Heritage Program Offices $^{*}$}

\author{
Alabama Natural Heritage Section \\ State Lands Division \\ Department of Conservation \& Natural \\ Resources \\ Folsom Administration Building \\ 64 N. Union Street, Room 421 \\ Montgomery, AL 36130 \\ 334/242-3484 Fax: 334/242-0098 \\ Internet: alnhp@wsnet.com \\ Alaska Natural Heritage Program \\ 707 A Street, Suite 208 \\ Anchorage, AK 99501 \\ 907/257-2702 Fax: 907/258-9139 \\ Back-up Fax: 907/276-6847 \\ Internet: ANRL@ORION.alaska.edu \\ Arizona Heritage Data Management \\ System \\ Arizona Game \& Fish Department \\ WM-H \\ 2221 W. Greenway Road \\ Phoenix, AZ 85023 \\ 602/789-3612 Fax: 602/789-3928 \\ Internet: hdms@gf.state.az.us \\ Internet: hdms1@gf.state.az.us \\ Arkansas Natural Heritage Commission \\ Suite 1500, Tower Building \\ 323 Center Street \\ Little Rock, AR 72201 \\ 501/324-9150 Fax: 501/324-9618
}

\author{
California Natural Heritage Division \\ Department of Fish \& Game \\ $1220 \mathrm{~S}$ Street \\ Sacramento, CA 95814 \\ 916/322-2493 Fax: 916/324-0475 \\ Colorado Natural Heritage Program \\ Colorado State University \\ 254 General Services Building \\ Fort Collins, CO 80523 \\ 970/491-1309 Fax: 970/491-3349
}

Internet: heritage@lamar.colostate.edu

Connecticut Natural Diversity Database

Natural Resources Center

Department of Environmental Protection

79 Elm Street, Store Level

Hartford, CT 06106-5127

860/424-3540 Fax: 860/424-4058

Delaware Natural Heritage Program

Division of Fish \& Wildlife

Department of Natural Resources \&

Environmental Control

4876 Hay Point Landing Road

Smyrna, DE 19977

302/653-2880 Fax: 302/653-3431

District of Columbia Natural Heritage

Program

13025 Riley's Lock Road

Poolesville, MD 20837

301/427-1354 Fax: 301/427-1355

"Source: http:/www.abi.org/nhp/directory 
Florida Natural Areas Inventory 1018 Thomasville Road

Suite 200-C

Tallahassee, FL 32303

904/224-8207; Fax: 904/681-9364.

Georgia Natural Heritage Program

Wildlife Resources Division

Georgia Department of Natural Resources

2117 U.S. Highway 278 S.E.

Social Circle, GA 30279

706/557-3032 or 770/918-6411

Fax: 706/557-3033; 706/557-3040

Internet:

natural_heritage@mail.dnr.state.ga.us

Hawaii Natural Heritage Program

The Nature Conservancy of Hawaii

1116 Smith Street, Suite 201

Honolulu, HI 96817

808/537-4508 Fax: 808/545-2019

Idaho Conservation Data Center

Department of Fish \& Game

600 South Walnut Street, Box 25

Boise, ID 83707-0025

208/334-3402 Fax: 208/334-2114

Illinois Natural Heritage Division

Department of Natural Resources

524 South Second Street

Springfield, IL 62701-1787

217/785-8774 Fax: 217/785-8277

Indiana Natural Heritage Data Center

Division of Nature Preserves

Department of Natural Resources

402 West Washington Street, Room W267

Indianapolis, IN 46204

317/232-4052 Fax: 317/233-0133
Iowa Natural Areas Inventory

Department of Natural Resources

Wallace State Office Building

Des Moines, IA 50319-0034

515/281-8524 Fax: 515/281-6794

Kansas Natural Heritage Inventory

Kansas Biological Survey

2041 Constant Avenue

Lawrence, KS 66047-2906

913/864-3453 Fax: 913/864-5093

Kentucky Natural Heritage Program

Kentucky State Nature Preserves

Commission

801 Schenkel Lane

Frankfort KY 40601

502/573-2886 Fax: 502/573-2355

Louisiana Natural Heritage Program

Department of Wildlife \& Fisheries

P.O. Box 98000

Baton Rouge, LA 70898-9000

504/765-2821 Fax: 504/765-2607

Maine Natural Areas Program

Department of Conservation

(FedEx/UPS: 159 Hospital Street)

93 State House Station

Augusta, ME 04333-0093

207/287-8044 Fax: 207/287-8040

Internet: mnap@state.me.us

Web site:

http://www.state.me.us/doc/mnap/home.htm

Maryland Heritage and Biodiversity Conservation Programs

Department of Natural Resources

Tawes State Office Building, E-1

Annapolis, MD 21401

410/974-2870 Fax: 410/974-5590 
Massachusetts Natural Heritage

\& Endangered Species Program

Division of Fisheries \& Wildlife

Route 135

Westborough, MA 01581

508/792-7270 ext. 200 Fax: 508/792-7275

Michigan Natural Features Inventory

Mason Building, 5th floor

(FedEx/UPS: $530 \mathrm{~W}$ Allegan, 48933)

Box 30444

Lansing, MI 48909-7944

517/373-1552 Fax: 517/373-6705

Minnesota Natural Heritage \& Nongame

Research

Department of Natural Resources

500 Lafayette Road, Box 7

St. Paul, MN 55155

612/297-4964 Fax: 612/297-4961

Mississippi Natural Heritage Program

Museum of Natural Science

111 North Jefferson Street

Jackson, MS 39201-2897

601/354-7303 Fax: 601/354-7227

Missouri Natural Heritage Database

Missouri Department of Conservation

P.O. Box 180

(FedEx: 2901 West Truman Blvd)

Jefferson City, MO 65102-0180

314/751-4115 Fax: 314/526-5582

Montana Natural Heritage Program

State Library Building

1515 E. 6th Avenue

Helena, MT 59620

406/444-3009 Fax: 406/444-0581

Internet: mtnhp@nris.msl.mt.gov

Homepage/World Wide Web:

http://nris.msl.mt.gov/mtnhp/nhp-dir.html
Nebraska Natural Heritage Program

Game and Parks Commission

2200 North 33rd Street

P.O. Box 30370

Lincoln, NE 68503

402/471-5421 Fax: 402/471-5528

\section{Nevada Natural Heritage Program}

Department of Conservation \& Natural Resources

1550 E. College Parkway, Suite 145

Carson City, NV 89710

702/687-4245 Fax: 702/885-0868

New Hampshire Natural Heritage

Inventory

Department of Resources \& Economic

Development

172 Pembroke Street

P.O. Box 1856

Concord, NH 03302

603/271-3623 Fax: 603/271-2629

New Jersey Natural Heritage Program Office of Natural Lands Management 22 South Clinton Avenue, CN404

Trenton, NJ 08625-0404

609/984-1339 Fax: 609/984-1427

New Mexico Natural Heritage Program

University of New Mexico

2500 Yale Boulevard, SE, Suite 100

Albuquerque, NM 87131-1091

505/277-1991 Fax: 505/277-7587

New York Natural Heritage Program

Department of Environmental

Conservation

700 Troy-Schenectady Road

Latham, NY 12110-2400

518/783-3932 Fax: 518/783-3916

518/783-3946 
North Carolina Heritage Program

NC Department of Environment, Health

\& Natural Resources

Division of Parks Recreation

P.O. Box 27687

Raleigh, NC 27611-7687

919/733-7701 Fax: 919/715-3085

North Dakota Natural Heritage Inventory

North Dakota Parks \& Recreation

Department

1835 Bismarck Expressway

Bismarck, ND 58504

701/328-5357 Fax: 701/328-5363

Ohio Natural Heritage Data Base

Division of Natural Areas \& Preserves

Department of Natural Resources

Fountain Square, Building F-1

Columbus, $\mathrm{OH} 43224$

614/265-6453 Fax: 614/267-3096

Internet: wiewissr@freenet.columbus.oh.us

Oklahoma Natural Heritage Inventory

Oklahoma Biological Survey

111 East Chesapeake Street

University of Oklahoma

Norman, OK 73019-0575

405/325-1985 Fax: 405/325-7702

Web site:

http://obssun02.uoknor.edu/biosurvey/onhi/home.html

Oregon Natural Heritage Program

Oregon Field Office

821 SE 14th Avenue

Portland, OR 97214

503/731-3070; 230-1221 Fax: 503/230-9639

Pennsylvania Natural Diversity Inventory

PNDI-East

The Nature Conservancy

34 Airport Drive

Middletown, PA 17057

717/948-3962 Fax: 717/948-3957
Rhode Island Natural Heritage Program

Department of Environmental

Management

Division of Planning \& Development

83 Park Street

Providence, RI 02903

401/277-2776, x4308 Fax: 401/277-2069

South Carolina Heritage Trust

SC Department of Natural Resources

P.O. Box 167

Columbia, SC 29202

803/734-3893

Fax: 803/734-6310 (Call first)

South Dakota Natural Heritage Data Base SD Department of Game, Fish \& Parks Wildlife Division

523 E. Capitol Avenue

Pierre, SD 57501-3182

605/773-4227 Fax: 605/773-6245

Tennessee Division of Natural Heritage

Department of Environment \& Conservation 401 Church Street

Life and Casualty Tower, 8th Floor

Nashville, TN 37243-0447

615/532-0431 Fax: 615/532-0614

Texas Biological and Conservation Data

System

3000 South IH-35, Suite 100

Austin, TX 78704

512/912-7011 Fax: 512/912-7058

Utah Natural Heritage Program

Division of Wildlife Resources

1596 West North Temple

Salt Lake City, UT 84116

801/538-4761 Fax: 801/538-4709 
Vermont Nongame \& Natural Heritage

Program

Vermont Fish \& Wildlife Department

103 S. Main Street, 10 South

Waterbury, VT 05671-0501

802/241-3700 Fax: 802/241-3295

Virginia Division of Natural Heritage

Department of Conservation \& Recreation

Main Street Station

1500 E. Main Street, Suite 312

Richmond, VA 23219

804/786-7951 Fax: 804/371-2674

Washington Natural Heritage Program

Department of Natural Resources

(FedEx: 1111 Washington Street, SE)

P.O. Box 47016

Olympia, WA 98504-7016

360/902-1340 Fax: 360/902-1783

West Virginia Natural Heritage Program

Department of Natural Resources

Operations Center

Ward Road, P.O. Box 67

Elkins, WV 26241

304/637-0245 Fax: 304/637-0250

Wisconsin Natural Heritage Program

Endangered Resources/4

Department of Natural Resources

101 S. Webster Street, Box 7921

Madison, WI 53707

608/266-7012 Fax: 608/266-2925

Wyoming Natural Diversity Database

1604 Grand Avenue, Suite 2

Laramie, WY 82070

307/745-5026

Fax: 307/745-5026 (Call first)

Internet: wynd@internetmci.com 


\section{Appendix C: Selecting a Consultant}

Usually, a consultant will be selected in the context of the tasks described in Appendix A. Some general criteria to consider (adapted from Nelson 1985) are:

1. Specialized training in identification of the species to be surveyed. Most often will entail relevant college course work.

2. Knowledge of the locally occurring species.

3. Experience in field studies and relevant survey methods.

4. Familiarity with Federal and state laws and regulations that the survey is designed to address and those that govern survey activities (e.g., trapping and collecting).

5. Demonstrated ability to analyze information/data and prepare comprehensive and detailed technical reports.

6. Certification by professional society and prior customer satisfaction.

7. Enthusiasm for field studies and the physical capability to conduct the work.

8. Possession of state and Federal permits necessary for conducting the surveys, or ability to obtain these permits.

In many cases, consultants meeting these criteria will be found at the state Natural Heritage Program. According to Army Regulation 200-3 (Chapter 2-7-c), competitive bids are not required for contracts for these kinds of services from state or local agencies. Also, a Memorandum of Agreement exists between the Department of Defense and The Nature Conservancy which can facilitate these contracts. 


\section{USACERL DISTRIBUTION}

\begin{tabular}{|c|c|}
\hline Chief of Engineors & FORSCOM \\
\hline $\begin{array}{l}\text { ATTN: CEHEC-IM-LH (2) } \\
\text { ATTN: CEHEC-IM-LP (2) }\end{array}$ & Forts Gillem \& McPherson 30330 \\
\hline ATTN: CECG & ATTN: FCEN \\
\hline ATTN: CECC-P & Installations: (20) \\
\hline ATTN: CECC-A & 6th Infantry Division (Light) \\
\hline ATTN: CECW & ATTN: APVR-DE 99505 \\
\hline ATTN: CECW-O & ATTN: APVR-WF-DE 99703 \\
\hline ATTN: CECW-P & \\
\hline ATTN: CECW-PR & TRADOC \\
\hline ATTN: CEMP & Fort Monroe 23651 \\
\hline ATTN: CEMP-E & ATTN: ATBO-G \\
\hline ATTN: CEMP-C & Installations: (20) \\
\hline ATTN: CEMP-M & \\
\hline ATTN: CEMP-R & Fort Belvoir 22060 \\
\hline ATTN: CERD-C & ATTN: CETEC-IM-T \\
\hline ATTN: CERD-ZA & ATTN: CETEC-ES $22315-3803$ \\
\hline ATTN: CERD-L & ATTN: Water Resources Support Ctr \\
\hline ATTN: CERD-M (2) & \\
\hline ATTN: DAIM-FDP & USA Natick RD\&E Center 01760 \\
\hline ATTN: DAIM-ED-R (5) & $\begin{array}{l}\text { ATTN: STRNC-DT } \\
\text { ATTN: AMSSC-S-IMI }\end{array}$ \\
\hline CECPW 22310-3862 & \\
\hline ATTN: CECPW-E & US Army Materials Tech Lab \\
\hline ATTN: CECPW-FT & ATTN: SLCMT.DPW 02172 \\
\hline ATTN: CECPW-ZC & \\
\hline & USARPAC 96858 \\
\hline US Army Engr District & ATTN: DPW \\
\hline ATTN: Library (40) & ATTN: APEN-A \\
\hline US Army Engr Division & SHAPE 09705 \\
\hline ATTN: Library (11) & ATTN: Infrastructure Branch LANDA \\
\hline US Army Europo & Area Engineer, AEDC-Area Office \\
\hline $\begin{array}{l}\text { ATTN: AEAEN-EH } 09014 \\
\text { ATTN: AEAEN-ODCS } 09014\end{array}$ & Arnold Air Force Station, TN 37389 \\
\hline 29th Aroa Support Group & HQ USEUCOM O9128 \\
\hline ATTN: AEUSG-K-E 09054 & ATTN: ECJ4-EN \\
\hline 222d BSB Unit \#23746 & \\
\hline ATTN: AETV-BHR-E 09034 & AMMRC 02172 \\
\hline 235th BSB Unit \#28614 & ATTN: DRXMR-AF \\
\hline ATTN: AETV-WG-AM 09177 & ATTN: DRXMR-WE \\
\hline 293d BSB Unit \#29901 & \\
\hline ATTN: AEUSG-MA-E 09086 & CEWES 39180 \\
\hline 409th Support Ballalion (Baso) & ATTN: Library \\
\hline ATTN: AETTG-DPW 09114 & \\
\hline 412th Base Support Battalion 09630 & CECRL 03755 \\
\hline ATTN: Unit 31401 & ATTN: Library \\
\hline 221st Base Support Battalion & \\
\hline ATTN: Unit 2962309096 & USA AMCOM \\
\hline CMTC Hohonlels 09173 & ATTN: Facilities Engr 21719 \\
\hline ATTN: AETTH-SB-DPW & ATTN: AMSMC-EH 61299 \\
\hline Mainz Germany 09185 & ATTN: Facilities Engr (3) 85613 \\
\hline ATTN: AETV.MNZ-E & \\
\hline 21st Support Command & USAARMC 40121 \\
\hline ATTN: DPW (8) & ATTN: ATZIC-EHA \\
\hline SETAF & \\
\hline ATTN: AESE-EN-D 09613 & Military Traffic Mgmt Command \\
\hline ATTN: AESE-EN 09630 & ATTN: MTEA-GB-EHP 07002 \\
\hline Supreme Alled Command & ATTN: MT-LOF 22041-5000 \\
\hline ATTN: ACSGEB 09703 & ATTN: MTE-SU-FE 28461 \\
\hline ATTN: SHIHB/ENGR 09705 & ATTN: MTW-IE 94626 \\
\hline INSCOM & Fort Leonard Wood 65473 \\
\hline ATTN: IALOG-I 22060 & ATTN: ATSE-DAC-LB (3) \\
\hline ATTN: IAV-DPW 22186 & ATTN: ATZT \\
\hline & ATTN: ATSE-CFLO \\
\hline USA TACOM $48397-5000$ & ATTN: ATSE-DAC-FL \\
\hline ATTN: AMSTA-XE & ATTN: Australian Liaison Office \\
\hline Defense Distribution Region East & Military Dist of WASH \\
\hline ATTN: ASCE-WI 17070-5001 & Fort MCNair \\
\hline & ATTN: ANEN-IS 20319 \\
\hline Defonso Distribution Region Wost & \\
\hline ATTN: ASCW-WG 95296.0100 & USA Engr Activity, Capital Area \\
\hline HQ XVIII Airborne Corps 28307 & \\
\hline ATTN: AFZA-DPW-EE & US Army ARDEC $07806-5000$ \\
\hline & ATTN: AMSTA-AR-IMC \\
\hline US Army Matoriel Command (AMC) & \\
\hline Alexandria, VA $22333-0001$ & Engr Societies Library \\
\hline ATTN: AMCEN-F & ATTN: Acquisitions 10017 \\
\hline Installations: $(20)$ & \\
\hline & U.S. EPA, Region V \\
\hline 4th Infantry Div (MECH) 80913-5000 & ATTN: AFRC-ENIL-FE 60561 \\
\hline
\end{tabular}

U.S. Army Environmental Center ATTN: SFIM-AEC-NR 21010 ATTN: SFIM-AEC-CR 64152 ATTN: SFIM-AEC-SR 30335-6801 ATTN: AFIM-AEC-WR 80022-2108

Defense Nuclear Agency ATTN: NADS 20305

Defense Logistics Agency ATTN: MMDIS 22060-6221

National Guard Bureau 20310 ATTN: NGB-ARI

US Military Academy 10996 ATTN: MAEN-A ATTN: Facilities Engineer ATTN: Geography \& Envr Engrg

Naval Facilities Engr Command ATTN: Facilities Engr Command (8) ATTN: Division Offices (11) ATTN: Public Works Center (8) ATTN: Naval Constr Battalion Ctr 93043 ATTN: Naval Facil. Engr. Service Ctr 93043-4328

8th US Army Korea ATTN: DPW (11)

USA Japan (USARJ)

ATTN: APAJ-EN-ES 96343

ATTN: HONSHU 96343

ATTN: DPW-Okinawa 96376

416th Engineer Command 60623 ATTN: Gibson USAR Ctr

US Army MEDCOM

ATTN: MCFA 78234-6000

Fitzsimons Army Medical Center 80045-5000 ATTN: MCHG-PW

Fort Detrick 21702-5000 ATTN: MCHS-IS

Fort Sam Houston 78234-5000 ATTN: MCFA-PW

Walter Reed Army Medical Center 20007-5001 ATTN: MCHL-PW

Tyndall AFB 32403

ATTN: HQAFCESAICES

ATTN: Engrg \& Srvc Lab

USA TSARCOM 63120 ATTN: STSAS-F

American Public Works Assoc. 64104-1806

US Army CHPPM

ATTN: MCHB-DE 21010

US Gov': Printing Office 2040 ATTN: Rec Sec/Deposit Sec (2)

Nat"l Institute of Standards \& Tech ATTN: Library 20893

Defense General Supply Center ATTN: DGSC-WI 23297-5000

Defense Construction Supply Center ATTN: DCSC.WI 43216-5000

Defense Tech Info Center 22060-6218 ATTN: DTIC-O (2) 

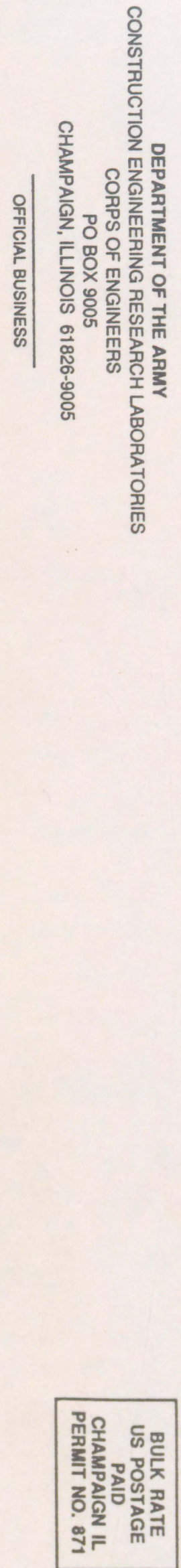